\title{
The effect of nutrient limitation on glycerol uptake and metabolism in continuous cultures of Pseudomonas aeruginosa
}

\author{
Steven G. Williams, Jacqueline A. Greenwood and Colin W. Jones
}

Author for correspondence: Colin W. Jones. Tel: +44533 523458. Fax: +44533523369.

Department of Biochemistry, University of Leicester, Leicester LE1 7RH, UK

\begin{abstract}
Pseudomonas aeruginosa NM48, a non-mucoid derivative of an alginateproducing strain isolated from a cystic fibrosis patient, was grown in batch culture with glycerol, glucose or succinate as carbon source, and in continuous culture $\left(D 0.05 \mathrm{~h}^{-1}\right)$ under glycerol or glucose limitation. Glycerol uptake, glycerol kinase and glycerol-3-phosphate dehydrogenase were induced by glycerol, but not by glucose or succinate. Linear uptake of $\left[{ }^{14} \mathrm{C}\right]$ glycerol by washed cells $\left(K_{m} \leqslant 2 \mu \mathrm{M}\right)$ was inhibited by unlabelled glycerol and glyceraldehyde, but not by cyanide or the uncoupling agent carbonyl cyanide p-trifluoromethoxyphenylhydrazone (FCCP), and was accompanied by substantial intracellular accumulation of glycerol-3-phosphate and/or dihydroxyacetone phosphate but not glycerol. Prolonged growth under glycerol limitation led to substantial increases in the activities and/or concentrations of the enzymes catalysing glycerol uptake and metabolism, together with a $48000 M_{r}$ outer-membrane protein which was also overexpressed following prolonged growth under glucose limitation. The $\mathbf{N}$ terminal amino acid sequence (AEAFSPN-) and electrophoretic properties of this protein were the same as those of the previously characterized glucose porin (OprB) from $P$. aeruginosa, indicating that this porin is active with both glucose and glycerol. It is concluded that during growth under glycerol limitation, glycerol is transported into P. aeruginosa NM48 via OprB and a high-affinity, binding-protein-independent facilitated-diffusion system.
\end{abstract}

Keywords: Pseudomonas aeruginosa, glycerol uptake and metabolism, glycerol-glucose porin, OprB

\section{INTRODUCTION}

Pseudomonas aeruginosa, an opportunistic pathogen, plays an important role in the mortality of cystic fibrosis patients - primarily as a result of its ability to infect the lungs and to develop an atypical mucoid form which produces copious amounts of alginate, a viscous expolysaccharide and an important virulence factor (May et al., 1991).

Phosphatidylcholine, a major component of lung surfactant, is degraded by $P$. aeruginosa to 1,2-diacylglycerol and phosphorylcholine by the action of phospholipase $C$ (Terry $t$ t al., 1992), following which the diacylglycerol is hydrolysed to glycerol and fatty acids by extracellular

Abbreviations: FCCP, p-trifluoromethoxyphenylhydrazone; KDO, 2-keto3-deoxyoctonate (3-deoxy-D-manno-2-octulosonate). lipases or esterases. Phosphatidylcholine and phosphorylcholine can be used by $P$. aeruginosa as sole sources of carbon, nitrogen and phosphorus for growth (Terry et al., 1991, 1992), and both lead to the emergence of mucoid sub-populations and elevated levels of alginate when supplied as limiting sources of phosphorus or nitrogen. Furthermore, glycerol is a particularly good carbon source for alginate synthesis in bronchial and cystic fibrosis isolates of $P$. aeruginosa (Marty et al., 1992) and readily promotes the appearance of mucoid colonies when supplied at high concentrations (Terry et al., 1991).

The nature of glycerol uptake in $P$. aeruginosa and related species is currently unclear. Physiological and biochemical evidence based on a low $K_{\mathrm{m}}$ for glycerol uptake by whole cells, together with the ability of partially purified osmotic-shock fluid to bind radiolabelled glycerol, has suggested the involvement of a high-affinity, energy- 
dependent transport system (Siegel \& Phibbs, 1979) associated with a periplasmic binding protein (Tsay et al., 1971); this uptake system was subsequently called GlpT (Schweizer, 1991). The transported glycerol is subsequently converted to glycerol 3-phosphate by an inducible glycerol kinase (GlpK), and thence under the action of glycerol-3-phosphate dehydrogenase (GlpD) to dihydroxyacetone phosphate, which is further catabolized by a branch of the Entner-Doudoroff pathway (McCowen et al., 1981). The genes encoding the glycerol uptake system, glycerol kinase and glycerol-3-phosphate dehydrogenase, appear to constitute a regulon (McCowen $e t$ al., 1981) which is under the control of a positive regulator (GlpR). Mutations in GlpR can be complemented with AgmR which is probably a DNA-binding protein of the type found in two-component signal-transduction systems (Schweizer, 1991), suggesting that induction of the glp genes may be at least partly under the control of such a system.

The growth of $P$. aeruginosa under nitrogen or phosphorus limitation, or in the presence of other environmental signals such as dehydration or high osmolarity, has been shown to activate genes encoding key enzymes of alginate synthesis (Deretic et al., 1990; DeVault et al., 1990; Zielinski et al., 1992). These genes are regulated by twocomponent signal-transduction systems involving AlgR/ $\mathrm{Alg} \mathrm{Q}$ and $\mathrm{AlgB}$, together with a histone-like element $\mathrm{A} \lg \mathrm{P}$, a positive regulator $\mathrm{Alg} \mathrm{T}(\mathrm{Alg} \mathrm{U}$ ) and a negative regulator AlgN (Deretic \& Konyecsni, 1989; Govan et al., 1992). Cross-talk between sensor-regulator systems has been demonstrated in vitro and raises the possibility that related sensors/effectors may interact to coordinate responses to environmental stimuli (Deretic et al., 1990; Schweizer, 1991). Such cross-talk between sensors/ effectors of glycerol metabolism and those of alginate synthesis could lead to further stimulation of alginate production. This, together with the probable importance of glycerol as a source of carbon within the lung, has prompted us to carry out more extensive physiological and biochemical investigations of glycerol uptake and metabolism in $P$. aeruginosa.

\section{METHODS}

Bacterial strains. Pseudomonas aeruginosa strain M48, a mucoid clinical isolate from a cystic fibrosis patient, was obtained from Dr P. Gale, Public Health Laboratory, Leicester Royal Infirmary, UK. This strain was reverted to its non-mucoid form, designated strain NM48, by incubation in liquid Luria broth medium for $72 \mathrm{~h}$ at $42{ }^{\circ} \mathrm{C}$ with no aeration (Deretic \& Konyecsni, 1989). Both strains were subsequently maintained on Pseudomonas isolation agar (Difco) and routinely plated cut on Luria broth agar supplemented with $60 \mathrm{mM}$ glycerol.

Growth of $\boldsymbol{P}$. aeruginosa. Batch culture was carried out at $37^{\circ} \mathrm{C}$ ( $\mathrm{pH} \mathrm{7.0)}$ in $500 \mathrm{ml}$ baffled flasks containing $150 \mathrm{ml}$ minimal medium C (Mian et al., 1978), modified to contain higher concentrations of $\mathrm{FeSO}_{4} \cdot 6 \mathrm{H}_{2} \mathrm{O}\left(10 \mathrm{mg} \mathrm{l}^{-1}\right)$ and $\left(\mathrm{NH}_{4}\right)_{2} \mathrm{SO}_{4}$ $\left(3.0 \mathrm{~g} \mathrm{l}^{-1}\right)$, with glycerol, glucose or succinate $\left(4 \mathrm{~g} \mathrm{l}^{-1}\right)$ as carbon substrate. Cells were harvested in mid-exponential phase. Growth on minimal-salts agar plates was carried out using modified medium $C$, supplemented with carbon substrate as above, with $1.5 \%(\mathrm{w} / \mathrm{v})$ agar. Continuous culture was carriced out in a 1-litre laboratory fermenter (LH Engineering 500 series, 0.9 litre working volume) at $37^{\circ} \mathrm{C}$ containing medium $\mathrm{C}$ modified as described above and supplemented with glycerol, glucose or succinate $\left(2 \mathrm{~g} \mathrm{l}^{-1}\right)$ as the growth-limiting nutrient. Iron was supplied separately as $\mathrm{FeSO}_{4} \cdot 6 \mathrm{H}_{2} \mathrm{O}\left(0 \cdot 21 \mathrm{~g} \mathrm{l}^{-1}\right.$ stock solution acidified with $2 \mathrm{ml} \mathrm{H}_{2} \mathrm{SO}_{4}$ ) to maintain an input concentration of $10 \mathrm{mg} \mathrm{l}^{-1}$. The $\mathrm{pH}$ of the medium was maintained at $7 \cdot 00 \pm 0.05$ by the separate addition of $2 \mathrm{M} \mathrm{KOH}$. Antifoam RD emulsion (Dow Corning) was diluted fivefold and added as required.

Measurement of carbon substrate uptake and disappearance. Rates of ${ }^{14} \mathrm{C}$-labelled glycerol, glucose and succinate uptake by washed cells were determined using the filtration procedure described by Cornish et al. (1988), except that cells were washed and resuspended to $1 \mathrm{mg}$ dry wt cells $\mathrm{ml}^{-1}$ in medium $\mathrm{C}\left(\mathrm{pH} 7 \cdot 0,37^{\circ} \mathrm{C}\right)$ lacking carbon source. Uptake was routinely measured in the same medium supplemented with $250 \mu \mathrm{M}$ substrate, and $50 \mu \mathrm{l}$ samples were taken at $15 \mathrm{~s}$ intervals over a period of $1 \mathrm{~min}$ (in some experiments glycerol uptake was also measured over $6 \mathrm{~min}$ with $1 \mathrm{mM}$ substrate, and $50 \mu \mathrm{l}$ samples were taken at $1 \mathrm{~min}$ intervals). Filters were immediately washed in medium $C$ lacking carbon source and immersed in $4 \mathrm{ml}$ OptiPhase Safe scintillation fluid (LKB) before measurement of radioactivity. Where indicated, the uncoupling agent FCCP was added to a final concentration of $20 \mu \mathrm{M}$ at least $10 \mathrm{~s}$ before the addition of the labelled carbon source. The $K_{m}$ for glycerol uptake was determined using glycerol concentrations in the range $5-50 \mu \mathrm{M}$, adjusting the cell density as required to achieve linear uptake for at least $1 \mathrm{~min}$ (it was not possible to use concentrations lower than $5 \mu \mathrm{M}$ due to the relatively low specific activity of the radiolabelled glycerol). Disappearance rates of $\left[{ }^{14} \mathrm{C}\right]$ glycerol were measured using a sampling manifold which had been modified to collect filtered supernatants; $50 \mu \mathrm{l}$ supernatant samples were added to $4 \mathrm{ml}$ OptiPhase Safe (LKB) before counting. The substrate specificity of the transport system was investigated by determining the extent to which unlabelled glycerol analogues decreased the rate of uptake of $\left[{ }^{14} \mathrm{C}\right]$ glycerol. Cell suspensions were incubated with unlabelled analogues for $10 \mathrm{~s}$ prior to the addition of $\left[{ }^{14} \mathrm{C}\right]$ glycerol.

Measurement of glycerol accumulation. Glycerol accumulation was measured by incubating washed cells in modified medium C (1 mg dry wt cells $\left.\mathrm{ml}^{-1}\right)$ with $\left[{ }^{14} \mathrm{C}\right]$ glycerol $(100 \mu \mathrm{M})$. Samples $(100 \mu \mathrm{l})$ were taken after $10 \mathrm{~s}$, collected by filtration and the filters rapidly immersed in $5 \mathrm{ml}$ boiling water. Aqueous extracts prepared from five filters were pooled, lyophilized and the residue redissolved in $0.2 \mathrm{ml}$ of water. Samples were then subjected to HPLC or paper chromatography.

Measurement of the re-swelling of plasmolysed cells due to solute uptake. Permeation of glycerol and related substrates into washed cells was measured at $25^{\circ} \mathrm{C}$ by the method of Heller et al. (1980), except that MOPS buffer was replaced by modified medium $\mathrm{C}(\mathrm{pH} 7 \cdot 0)$ lacking a carbon source. Washed cells $(25 \mu \mathrm{l}$ of a $25 \mathrm{mg}$ dry wt cells $\mathrm{ml}^{-1}$ suspension) were added to $1 \mathrm{ml}$ of $250 \mathrm{mM}$ substrate, and mixed rapidly. After initial plasmolysis due to the high external osmotic pressure, re-swelling occurred as the substrate permeated into the cell and was measured spectrophotometrically at $600 \mathrm{~nm}$. The time required for $50 \%$ re-swelling was expressed as the half-time, $t_{\frac{1}{2}}(\mathrm{~min})$.

Osmotic shock. Osmotic shock was carried out by a modification of the method of Tsay et al. (1971). Washed cells were resuspended in modified medium $C$ containing $20 \%(\mathrm{w} / \mathrm{v})$ sucrose to a final concentration of approximately $15 \mathrm{mg}$ dry wt cells $\mathrm{ml}^{-1}$. The suspension was stirred at $37^{\circ} \mathrm{C}$ and EDTA $(100 \mathrm{mM})$ was added as ten aliquots $\left(5 \mu \mathrm{ml}^{-1}\right)$ over a period of $10 \mathrm{~min}$ to a final concentration of $5 \mathrm{mM}$. Cells were removed by 
centrifugation at $10000 \mathrm{~g}$ for $10 \mathrm{~min}$ and the supernatant (shock fluid) was tested for its capacity to bind ${ }^{14} \mathrm{C}$-labelled substrate using equilibrium dialysis (Cornish et al., 1988).

Plasmolysis. The method of Cheng et al. (1970) was used to plasmolyse washed cells with $0.2 \mathrm{mM} \mathrm{MgCl}_{2}$ in $0.01 \mathrm{M}$ Tris $(\mathrm{pH} \mathrm{8.4)}$. Liptake rates of plasmolysed cells were measured as described above. Alternatively, plasmolysed cells were removed by centrifugation at $10000 \mathrm{~g}$ for $10 \mathrm{~min}$ and the capacity of the supernatant to bind ${ }^{14} \mathrm{C}$-labelled substrate was assayed using equilibrium dialysis.

Preparation of broken cells and high speed membrane fraction. Washed cells were resuspended to $5 \mathrm{mg}$ dry wt cells $\mathrm{ml}^{-1}$ in $0 \cdot 1 \mathrm{M}$ Tris $/ \mathrm{HCl}$ buffer $(\mathrm{pH} \mathrm{7.6)}$ ) and broken by sonication for $6 \times 30 \mathrm{~s}$ at an amplitude of $12 \mu \mathrm{m}$. The sonicate was centrifuged at $8000 \mathrm{~g}$ for $10 \mathrm{~min}$ to remove cell debris, and $5 \mathrm{ml}$ of the resultant cell-free extract was then centrifuged at $100000 \mathrm{~g}$ for $2 \mathrm{~h}$ to produce a high-speed membrane fraction (HSMF) which was subsequently resuspended in $1 \mathrm{ml} 0 \cdot 1 \mathrm{M}$ Tris $/ \mathrm{HCl}$ buffer ( $\mathrm{pH} 7.6)$.

Separation of inner and outer membranes. This was carried out essentially as described by Hancock \& Nikaido (1978) except that ribonuclease, deoxyribonuclease and $p$-toluenesulfonyltuoride were omitted from the preparation. The HSMF was resuspended in $30 \mathrm{mM}$ Tris/ $\mathrm{HCl}$ buffer $(\mathrm{pH} \mathrm{7.6)}$ and approximately $1 \mathrm{ml}$ was applied directly to a four-step sucrose gradient $(54 \%, 58 \%, 64 \%, 70 \%, \mathrm{w} / \mathrm{v})$. Each step plus its interface with the next step was collected separately, then centrifuged at $100000 \mathrm{~g}$ for $2 \mathrm{~h}$ and the pelleted membranes resuspended in $1 \mathrm{ml} 0.1 \mathrm{M}$ Tris/ $\mathrm{HCl}$ buffer ( $\mathrm{pH} \mathrm{7.6)}$ ).

Enzyme assays. Glycerol kinase and glycerol-3-phosphate dehydrogenase were assayed as described by McCowen $t$ al. (1981) except that nitroblue-tetrazolium (NITRO-B'T) was replaced with 2,6-dichlorophenol-indophenol (DCPIP) $(64.5 \mu \mathrm{M})$ in the dehydrogenase assay. Succinate dehydrogenase was assaved as described by Kasahara \& Anraku (1974). All enzymes were assayed at $37^{\circ} \mathrm{C}$.

Partial purification of glycerol kinase and the $48000 M$, protein. Sucrose/EDTA-shocked cells were pelleted by centrifugation at $10000 \boldsymbol{g}$ for $10 \mathrm{~min}$, resuspended in $20 \mathrm{mM}$ Bis-Tris (pH 6.8), incubated on ice for $20 \mathrm{~min}$, then centrifuged at $10000 \mathrm{~g}$ for $10 \mathrm{~min}$. The resultant shock fluid, containing a proportion of the total glycerol kinase, was filtered through an acrodisc $(0.2 \mu \mathrm{m}$ pore size; Gelman) and loaded on a Mono $\mathrm{Q}$ FPLC column (Pharmacia) pre-equilibrated with $20 \mathrm{mM}$ BisTris/ $\mathrm{HCl}$ buffer ( $\mathrm{pH} \mathrm{6.8).} \mathrm{Glycerol} \mathrm{kinase} \mathrm{was} \mathrm{eluted} \mathrm{using} \mathrm{a}$ linear $\mathrm{KCl}$ gradient $(0-400 \mathrm{mM}$ over $20 \mathrm{~min})$, and eluent fractions were assayed for glycerol kinase activity and analysed using SDS-PAGE. The $48000 M_{\mathrm{r}}$ protein was solubilized from outer-membrane preparations using $0.2 \%(\mathrm{w} / \mathrm{v})$ SDS, $5 \mathrm{mM}$ EDTA in $10 \mathrm{mM}$ Tris/ $\mathrm{HCl}$ buffer $(\mathrm{pH} 8.0)$, and then centrifuged at $100000 \mathrm{~g}$ for $2 \mathrm{~h}$ to remove residual membranes. The resultant supernatant was filtered through an acrodisc $(0 \cdot 2 \mu \mathrm{m}$ pore size) and loaded on a Superose 12 FPLC column (Pharmacia) pre-equilibrated with $0.2 \%$ (w/v) SDS, $5 \mathrm{mM}$ EDTA in $10 \mathrm{mM}$ Tris/HCl buffer (pH 8.0) and eluted with the same mixture. Eluent fractions were analysed by SDS-PAGE.

Analytical procedures. 2-Keto-3-deoxyoctonate (KDO) was measured by the method of Osborn (1963). Paper chromatography and identification of spots as phosphate esters using molybdate/perchloric acid was carried out as described by Dawson et al. (1986). HPLC was performed at room temperature $\left(18-20^{\circ} \mathrm{C}\right)$ on a Bio-Rad Aminex HPX-87H ion-exclusion column linked to a Bio-Rad Series 800 chromatograph operating at a flow rate of $0 \cdot 2 \mathrm{ml} \mathrm{min}^{-1}$ with $2 \mathrm{mM} \mathrm{H}_{2} \mathrm{SO}_{4}$ as solvent.
Other procedures. Discontinuous SDS-PAGE was carried out as described by Cornish et al. (1988). Protein content was determined by scanning SDS-polyacrylamide gels at $633 \mathrm{~nm}$ using an LKB laser densitometer linked to a recording integrator. $\mathrm{N}$-terminal sequencing of the $48000 M_{\mathrm{r}}$ protein was carried out by blotting an SDS-polyacrylamide gel containing the partially purified protein on to nitrocellulose, eluting the protein on to a polyvinylidine difluoride disc, and then sequencing with a model 470 gas-phase sequencer (Applied Biosystems).

Chemicals. $\left[\mathrm{U}^{-14} \mathrm{C}\right] \mathrm{Glycerol}\left(153 \mathrm{mCi} \mathrm{mmol}^{-1} ; 5 \cdot 7 \mathrm{GBq} \mathrm{mmol}^{-1}\right)$ was supplied by $\mathrm{NEN}, \mathrm{D}-\left[\mathrm{U}^{14} \mathrm{C}\right]$ glucose $\left(270 \mathrm{mCi} \mathrm{mmol}^{-1}\right.$; $\left.10 \mathrm{GBq} \mathrm{mmol}^{-1}\right)$ and $\left[2,3-{ }^{14} \mathrm{C}\right]$ succinic acid $\left(40 \mathrm{mCi} \mathrm{mmol}^{-1}\right.$; $1.5 \mathrm{GBq} \mathrm{mmol}^{-1}$ ) were supplied by Amersham. Antifoam RD emulsion (Dow Corning) was supplied by BDH. All other chemicals were obtained from Sigma, Fisons or BDH and were of the highest grade available.

\section{RESULTS}

\section{Induction of glycerol-metabolizing enzymes}

P. aeruginosa M48 and its non-mucoid derivative NM48 both grew well on mineral-salts agar plates supplemented with glycerol as carbon source, under which conditions M48 produced copious amounts of alginate. Both strains also grew well in batch culture with glycerol, glucose or succinate as carbon source.

Washed cells or cell extracts of strain NM48 prepared from cells grown in batch culture with glycerol as carbon source exhibited high glycerol uptake, glycerol kinase and glycerol-3-phosphate dehydrogenase activities (Table 1). In contrast, activities were extremely low or absent following growth on glucose or succinate, indicating that these enzymes are induced by glycerol but not by glucose or succinate (as has previously been found for other strains of $P$. aeruginosa; McCowen et al., 1981). Similar activities for glycerol uptake, glycerol kinase and glycerol3-phosphate dehydrogenase were also found for the

Table 1. Glycerol uptake, glycerol kinase and glycerol-3phosphate dehydrogenase activities of $P$. aeruginosa NM48 following growth in batch culture

P. aeruginosa NM48 was grown in batch culture with glycerol, glucose or succinate as the carbon source, and assayed for various enzyme activities as described in Methods. The results are the mean of up to eight independent determinations and are expressed where appropriate, \pm SEM.

\section{Activity [nmol $\mathrm{min}^{-1}$ (mg dry wt cells $)^{-1}$ ]}

Carbon source for growth: Glycerol Glucose Succinate

Glycerol uptake

$\begin{array}{ll}21 \cdot 3 \pm 2 \cdot 5(8) & 1 \cdot 5 \\ 18 \cdot 9 \pm 3 \cdot 9(8) & 1 \cdot 0 \\ 19 \cdot 7 \pm 4 \cdot 3(6) & 0 \cdot 0\end{array}$

$0 \cdot 0$

Glycerol kinase

Glycerol-3-phosphate

$19 \cdot 7 \pm 4 \cdot 3(6)$

$0 \cdot 0$

$0 \cdot 0$

dehydrogenase 


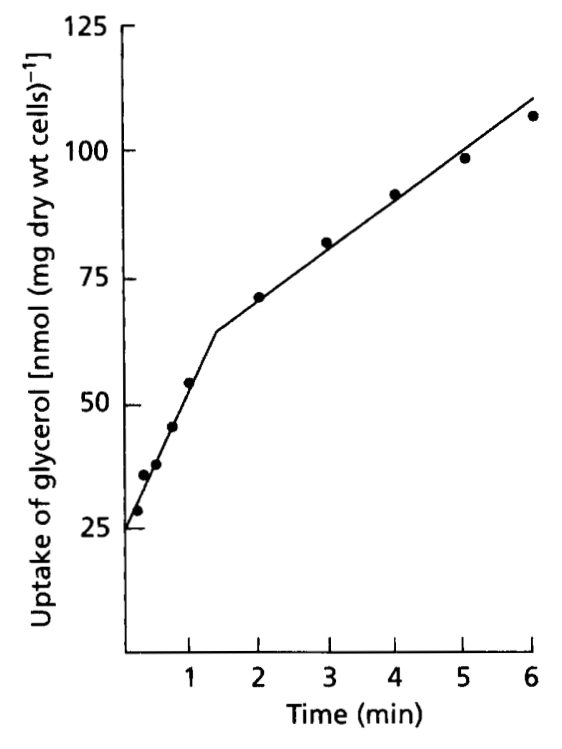

Fig. 1. Uptake of $\left[{ }^{14} \mathrm{C}\right]$ glycerol by washed cells of $P$. aeruginosa NM48 prepared from a glycerol-limited continuous culture $(D$, $0.05 \mathrm{~h}^{-1}$ ) as described in Methods.

parent strain M48, whereas the activity of the alginate biosynthetic enzyme phosphomannomutase was more than double in M48 (data not shown). This would indicare that the loss of mucoidy was due to a lack of biosynthet $\mathrm{c}$ capacity rather than a change in the nature of glycerol metabolism.

\section{Glycerol uptake and metabolism in cells grown under glycerol limitation}

In order to investigate glycerol uptake and metabolism ir more detail, $P$. aeruginosa NM48 was grown in continuous culture under glycerol limitation at low dilution rate $\left(0.05 \mathrm{~h}^{-1}\right.$, compared with a maximum specific growth rate of $0.21 \mathrm{~h}^{-1}$ in batch culture), thus ensuring that the residual concentration of glycerol in the culture was well below the affinity constant $\left(K_{\mathrm{s}}\right)$ of the culture for glycerol. The culture was initially difficult to maintain under glycerol limitation but finally stabilized after approximately 29 generations, at which point no residual glycerol was detectable in the culture supernatant.

In the absence of a suitable radiolabelled, non-metabolizable analogue, glycerol uptake was measured using $\left[{ }^{14} \mathrm{C}\right]$ glycerol. Uptake of the latter by washed cells was linear for 1-2 min (Fig. 1), during which time it exhibited an average rate of $22 \mathrm{nmol} \mathrm{min}^{-1}$ ( $\mathrm{mg} \mathrm{dry} \mathrm{wt} \mathrm{cells)}{ }^{-1}$ and a $K_{\mathrm{m}}$ for glycerol of $\leqslant 2 \mu \mathrm{M}$. This uptake rate was slightly lower than the rate of glycerol utilization $\left(q_{\text {giycerol }}\right)$ by the growing culture (cell density $0.57 \mathrm{~g} \mathrm{dry} \mathrm{wt} \mathrm{cells} 1^{-1}$ ) which was calculated to be $2 \times 0.05 \times 10^{6} /(92 \times 0.57 \times 60)=$ $31 \mathrm{nmol} \mathrm{min}^{-1}$ ( $\mathrm{mg}$ dry wt cells) ${ }^{-1}$. The rate then fell by about $66 \%$ to a new approximately linear rate which was maintained for at least another $4 \mathrm{~min}$. The rate of $\left[{ }^{14} \mathrm{C}\right]$ glycerol disappearance catalysed by washed cells was similar to the initial linear rate of glycerol uptake and remained unchanged for the entire $6 \mathrm{~min}$, indicating that the diminished rate of glycerol uptake after 2 min was probably due to the loss of radiolabelled carbon dioxide as a result of glycerol metabolism. None of these uptake or disappearance rates were affected by preincubation of the cells with $10 \mathrm{mM}$ glucose, indicating that any energy requirement for glycerol uptake was satisfied by the oxidation of endogenous substrates or the further oxidation of transported glycerol. Extrapolation of glycerol uptake back to zero time yielded a significant intercept, which was abolished when cells were partially lysed by treatment with sucrose/EDTA and was much reduced in cells grown under non-inducing conditions, indicating that the intercept reflected a very rapid phase of glycerol uptake rather than binding. In contrast to the high intercept seen during the uptake of $\left[{ }^{14} \mathrm{C}\right]$ glycerol by cells grown under glycerol limitation (Fig. 2a), no significant intercept was seen during the uptake of $\left[{ }^{14} \mathrm{C}\right]$ succinate by these cells or of $\left[{ }^{14} \mathrm{C}\right]$ glucose by cells grown under glucose limitation (Fig. 2b, c), indicating that the intercept is specific to glycerol uptake.

FCCP ( $p$-trifluoromethoxyphenylhydrazone), a powerful uncoupling agent, significantly diminished the intercept but had no effect on the rate of glycerol uptake, whereas it strongly decreased the rates of glucose and succinate uptake (both of which unequivocally occur via periplasmic binding-protein-dependent active-transport systems ; Stinson et al., 1976) (Fig. 2a, b, c). The absence of a similar binding-protein-dependent transport system for glycerol was confirmed by subjecting washed cells to osmotic shock and then showing by equilibrium dialysis that the resultant sucrose/EDTA shock fluid did not bind $\left[{ }^{14} \mathrm{C}\right]$ glycerol (contrast Tsay et al., 1971). Furthermore, treatment of washed cells with $0.2 \mathrm{M} \mathrm{MgCl}_{2}$ to remove the glucose- and succinate-binding proteins (Stinson et al., 1976) inhibited succinate and glucose uptake much more strongly than glycerol uptake $(67 \%$ versus $25 \%$ ), and the washings again exhibited no $\left[{ }^{14} \mathrm{C}\right]$ glycerol-binding capacity.

HPLC analysis of cell extracts prepared $10 \mathrm{~s}$ after the addition of $\left[{ }^{14} \mathrm{C}\right]$ glycerol to washed cells revealed that $95 \%$ of the recovered label eluted as a single peak with a retention time characteristic of both glycerol 3-phosphate and dihydroxyacetone phosphate. It was not possible using either HPLC or paper chromatography to distinguish between these two compounds. No free glycerol was detected.

The rate of $\left[{ }^{14} \mathrm{C}\right]$ glycerol uptake by washed cells was approximately halved in the presence of an equimolar concentration of unlabelled glycerol. A 40-fold excess of glycerol, glyceraldehyde or erythritol inhibited glycerol uptake by $100 \%, 59 \%$ and $11 \%$ respectively, whereas glucose and xylitol had no effect. Neither glyceraldehyde or erythritol had any effect on glycerol kinase or glycerol3-phosphate dehydrogenase activity, suggesting that they specifically inhibited glycerol uptake.

Optical assays exploiting the osmotic re-swelling of Escherichia coli in hypertonic solutions have previously used high concentrations of glycerol and related substrates 

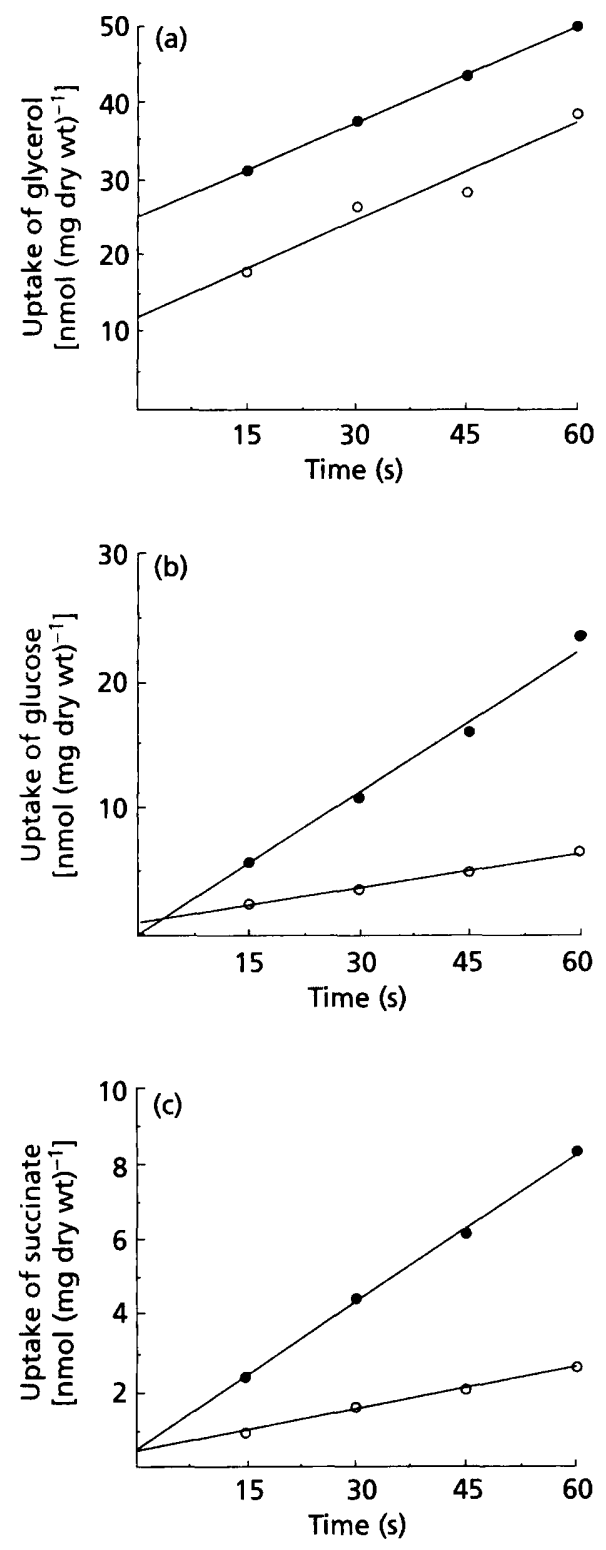

Fig. 2. Effect of FCCP on the uptake of (a) $\left[{ }^{14} \mathrm{C}\right]$ glycerol, (b) $\left[{ }^{14} \mathrm{C}\right]$ glucose and $(\mathrm{c})\left[{ }^{14} \mathrm{C}\right]$ succinate by washed cells of $P$. aeruginosa NM48 prepared from a glycerol-limited $(a, c)$ and a glucose-limited (b) continuous culture $\left(D, 0.05 \mathrm{~h}^{-1}\right)$ as described in Methods. No FCCP; $0,20 \mu \mathrm{M}$ FCCP.

to demonstrate the presence of a glycerol permease in this organism (Heller et al., 1980). Similar experiments carried out with $P$. aeruginosa NM48 demonstrated significant differences between washed cells prepared from induced or uninduced cultures. Permeation of glycerol into both types of cells was extremely rapid $\left(t_{\frac{1}{2}}<0.1 \mathrm{~min}\right)$, presumably reflecting entry predominantly by simple diffusion at the very high substrate concentrations necessarily employed in these experiments. In contrast, permeation of glyceraldehyde into uninduced cells was very much slower than into induced cells $\left(t_{\frac{1}{2}}>1.9 \mathrm{~min}\right.$, compared with $<0.1 \mathrm{~min}$ ), as also was the permeation of erythritol $\left(t_{\frac{1}{2}}>5.7 \mathrm{~min}\right.$, compared with $\left.<1.1 \mathrm{~min}\right)$, strongly sug- gesting that a permease is induced during growth on glycerol which greatly accelerates the rate of entry of lesspermeant glycerol analogues into the cell. Glucose entered both types of cells very slowly $\left(t_{\frac{1}{2}}>10 \mathrm{~min}\right)$.

Crude cell extracts prepared from cells grown in glycerollimited continuous culture $\left(D \quad 0.05 \mathrm{~h}^{-1}\right)$ exhibited a glycerol kinase activity of $86 \mathrm{nmol} \mathrm{min}{ }^{-1}$ (mg dry wt cells $^{-1}$ and a $K_{\mathrm{m}}$ for glycerol of $19 \mu \mathrm{M}$, similar to the value of 10-40 $\mu \mathrm{M}$ reported earlier for the purified enzyme from $P$. aeruginosa (McCowen et al., 1987) and an order of magnitude higher than the $K_{\mathrm{m}}$ for glycerol uptake, but much lower than the reported $K_{\mathrm{m}}(1.66 \mathrm{mM})$ of the glycerol-3-phosphate dehydrogenase for glycerol 3-phosphate (McCowen et al., 1981). This activity was higher than either the $q_{\text {glycerol }}$ of the growing culture or the rates of glycerol uptake and disappearance by washed cells, but is not quite sufficient to support the apparently very rapid rate of glycerol uptake over the first $15 \mathrm{~s}$ of the assay. However, it is possible that glycerol kinase activity is significantly higher in vivo since approximately $12 \%$ of the enzyme is membrane-bound and may therefore be activated by association with the glycerol permease, as has recently been suggested for E. coli (Voegele et al., 1993). The glycerol kinase was partially purified using FPLC and found to be comprised of a single type of subunit with an $M_{\mathrm{r}}$ of 51300 (cf. a reported $M_{\mathrm{r}}$ of 120000 for the native enzyme; McCowen et al., 1987), indicating that it probably exists as a homodimer. The glycerol-3-phosphate dehydrogenase activity of only $12 \mathrm{nmol} \mathrm{min}{ }^{-1}$ ( $\mathrm{mg}$ dry wt cells) ${ }^{-1}$ was well below the $q_{\text {glycerol }}$, suggesting that the activity of this enzyme was probably underestimated.

It is concluded from the above results that glycerol probably enters $P$. aeruginosa in a similar manner to E. coli, i.e. passively via an inducible high-affinity system (which, in contrast to previous reports, is energy-independent and does not involve a periplasmic binding-protein) before being trapped within the cell as a result of being rapidly phosphorylated to glycerol 3-phosphate by glycerol kinase. It is likely that the rate of glycerol uptake is determined by the glycerol kinase activity (as has also been reported for Enterococcus faecalis: Romano et al., 1990); this would imply that the kinase activity is particularly high during the initial intercept phase, probably reflecting the high availability of ATP (and perhaps also a physical association of the kinase with the putative permease), but is much lower during the subsequent linear phase or following the addition of FCCP.

\section{Selection of novel cultures which overexpress the enzymes of glycerol uptake and metabolism following prolonged growth of $P$. aeruginosa NM48 in glycerol-limited continuous culture}

After growing $P$. aeruginosa NM48 in glycerol-limited continuous culture for approximately 36 generations (culture A), the glycerol uptake rate had risen slightly and was accompanied by a substantial increase in glycerol kinase activity; no increase had occurred in glycerol-3phosphate dehydrogenase activity (Table 2). After ap- 
Table 2. Effect of prolonged growth in glycerol-limited continuous culture on the enzymes associated with glycerol uptake and metabolism in $P$. aeruginosa NM48

$P$. aeruginosa NM48 was grown for approximately 260 generations in glycerol-limited continuous culture $\left(D, 0.05 \mathrm{~h}^{-1}\right)$ and enzyme activities were measured at various stages as described in Methods. Enzyme concentrations expressed as \% cell protein were determined by SDS-PAGE and scanning laser densitometry. The $k_{\text {cat }}$ for glycerol kinase was calculated from its specific activity [nmol min ${ }^{-1}$ (mg dry wt cells) $)^{-1}$, concentration (\% cell protein) and native $M_{\mathrm{r}}(102600)$, assuming that protein comprises $65 \%$ of the dry cell weight. GK, glycerol kinase; G3PDH, glycerol-3-phosphate

dehydrogenase. The results are the mean of up to seven independent determinations and are expressed, where appropriate, \pm SEM. ND, Not determined.

\begin{tabular}{|c|c|c|c|c|}
\hline \multirow[t]{2}{*}{ Enzyme properties } & \multicolumn{4}{|c|}{ Culture } \\
\hline & NM48 & A & B & C \\
\hline $\begin{array}{l}\text { Glycerol uptake rate } \\
{\left[\text { nmol } \min ^{-1}(\mathrm{mg} \mathrm{dry} \mathrm{wt} \mathrm{cells})^{-1}\right]}\end{array}$ & $22 \cdot 3 \pm 1 \cdot 8$ & $29 \cdot 7 \pm 2 \cdot 5$ & $48 \cdot 0 \pm 4 \cdot 5$ & $80 \cdot 0 \pm 0 \cdot 3$ \\
\hline $\begin{array}{l}\text { GK activity } \\
\left.\left[\mathrm{nmol} \mathrm{min}^{-1} \text { (mg dry wt cells }\right)^{-1}\right]\end{array}$ & $45 \cdot 0 \pm 4 \cdot 7$ & $109 \cdot 0 \pm 7 \cdot 8$ & $186 \cdot 0 \pm 8 \cdot 8$ & $398 \cdot 0 \pm 49 \cdot 6$ \\
\hline $\begin{array}{l}\text { GK concentration } \\
\text { ( } \% \text { cell protein })\end{array}$ & $3 \cdot 5$ & $7 \cdot 4$ & $14 \cdot 4$ & $24 \cdot 3$ \\
\hline $\mathrm{GK} k_{\mathrm{cat}}\left(\mathrm{s}^{-1}\right)$ & $3 \cdot 4$ & $3 \cdot 9$ & $3 \cdot 4$ & $4 \cdot 3$ \\
\hline GK ( $\%$ membrane-bound $)$ & $12 \cdot 1 \pm 2 \cdot 1$ & ND & $23 \cdot 0 \pm 9 \cdot 9$ & $29 \cdot 3 \pm 8 \cdot 7$ \\
\hline $\begin{array}{l}\text { G3PDH activity } \\
{\left[\mathrm{nmol} \mathrm{min}^{-1} \text { (mg dry wt cells) }\right)^{-1} \text { ] }}\end{array}$ & $11.9 \pm 1 \cdot 7$ & $11 \cdot 6 \pm 2 \cdot 5$ & $18 \cdot 6 \pm 2 \cdot 3$ & $71 \cdot 0 \pm 4 \cdot 8$ \\
\hline $\begin{array}{l}48000 M_{\mathrm{r}} \text { protein } \\
(\% \text { cell protein) }\end{array}$ & $2 \cdot 7$ & 3.9 & 6.3 & $8 \cdot 7$ \\
\hline
\end{tabular}

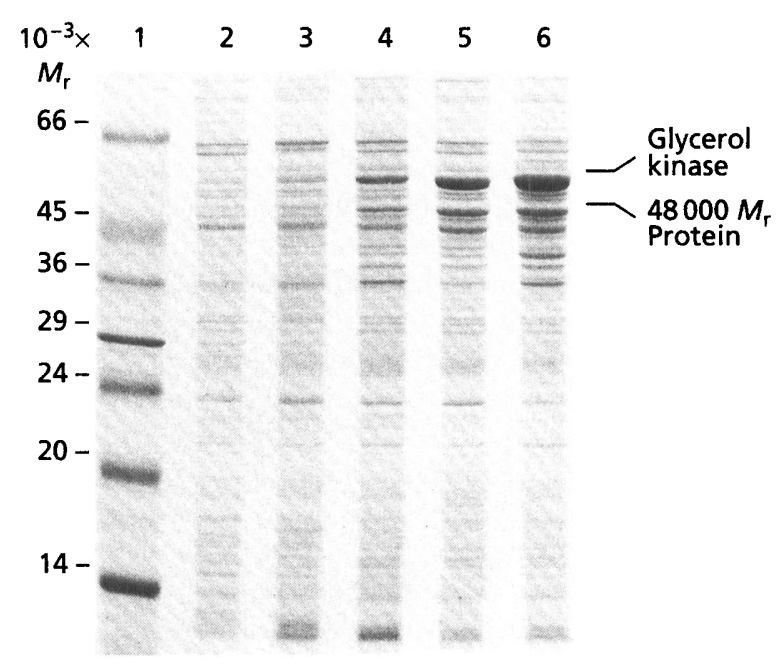

Fig. 3. Over-expression of glycerol kinase and the $48000 \mathrm{M}_{\mathrm{r}}$ protein during prolonged growth of $P$. aeruginosa NM48 in glycerol-limited continuous culture $\left(D, 0.05 \mathrm{~h}^{-1}\right)$. Samples of washed cells prepared from glycerol-batch cultures or glycerollimited continuous cultures were subjected to SDS-PAGE ( $30 \mu \mathrm{g}$ protein per track) as described in Methods. Tracks: $1, M_{\mathrm{r}}$ standards; 2, NM48 (batch); 3, NM48 (continuous); 4, culture A (continuous); 5, culture B (continuous); 6, culture C (continuous).

proximately 167 generations (culture B) the rate of glycerol uptake had increased further, together with the glycerol kinase and glycerol-3-phosphate dehydrogenase activities. After approximately 260 generations (culture C) the rate of glycerol uptake and the glycerol kinase activity had both increased further, and this was accompanied by a large increase in glycerol-3-phosphate dehydrogenase activity. Throughout the entire experiment the increases in glycerol uptake rate were accompanied by similar increases in the intercept, which reached a mean value of $42 \mathrm{nmol}$ ( $\mathrm{mg}$ dry wt cells) ${ }^{-1}$ in culture C. The increases in glycerol kinase activity were accompanied by essentially parallel increases in the concentration of the enzyme as determined by SDS-PAGE (Fig. 3; commensurate with an essentially constant $\left.k_{\text {cat }}\right)$, and by a sustained increase in the extent to which the enzyme was bound to the membrane. Analysis of osmotic shock fluid prepared from culture $C$ using equilibrium dialysis and SDS-PAGE again showed no evidence for the presence of a periplasmic glycerol-binding protein (in contrast to the positive evidence previously obtained using these methods for the presence of sugar-binding proteins in other similarly-evolved organisms: Cornish et al., 1988; Williams et al., 1990). SDS-PAGE also showed that the concentration of a $48000 M_{\mathrm{r}}$ protein increased approximately in parallel with that of glycerol kinase.

Comparison of the distribution of the strongly membranebound $48000 M_{\mathrm{r}}$ protein with that of KDO (a component of the lipopolysaccharide associated with the outer membrane) and of two inner-membrane markers (succinate dehydrogenase and glycerol-3-phosphate dehydrogenase) in various membrane fractions prepared by sucrose density-gradient centrifugation of a high-speed 
Table 3. Properties of inner and outer membranes of $P$. aeruginosa NM48

Inner and outer membranes were prepared from a $P$. aeruginosa NM48 high-speed membrane fraction (HSMF) and assayed as described in Methods. Fractions A-D are the individual fractions plus interfaces obtained following four-step sucrose density gradient centrifugation of the HSMF. A, $54 \%(\mathrm{w} / \mathrm{v})$ suctose (low density lipid); B, $58 \%$ (w/v) sucrose (mainly inner membrane); C, $64 \%$ (w/v) sucrose (mainly outer membrane); D, $70 \%(\mathrm{w} / \mathrm{v})$ sucrose (mainly outer membrane). After centrifugation, each pelleted fraction was resuspended to the same volume as the original HSMF $(1 \mathrm{ml})$. The results are expressed as percentages of the sum of the activities/concentrations in the various fractions $(A+B+C+D=100)$ and varied by no more than $\pm 6 \%$ between separate determinations. G3PDH, glycerol-3-phosphate dehydrogenase; SDH, succinate dehydrogenase.

\begin{tabular}{|lrrrc|}
\hline $\begin{array}{l}\text { Membrane } \\
\text { fraction }\end{array}$ & KDO & G3PDH & SDH & $\begin{array}{c}\mathbf{4 8 0 0 0} \boldsymbol{M}_{\mathbf{r}} \\
\text { protein }\end{array}$ \\
\hline A & 0 & 11 & 2 & 0 \\
B & 36 & 79 & 84 & 24 \\
C & 45 & 10 & 12 & 53 \\
D & 19 & 0 & 2 & 23 \\
\hline
\end{tabular}

membrane preparation showed that the $48000 M_{\mathrm{r}}$ protein was mainly associated with the outer membrane (Table 3 ). It should be noted, however, that as $24 \%$ of the $48000 M_{\mathrm{r}}$ protein was associated with the inner-membrane fraction and $12 \%$ of the succinate dehydrogenase (a known innermembrane protein) was associated with the outer-membrane fraction, the separation of the two membranes was not perfect and some cross-contamination had clearly occurred.

Analysis of culture samples by plating on nutrient agar showed that the original population of dome-shaped colonies was gradually accompanied by the appearance of a second type of colony which had a flatter morphology and was prone to lysis (possibly due to bacteriophage activity: Terry et al., 1991). These two main colonial types exhibited identical polypeptide profiles when analysed by SDS-PAGE following growth on nutrient broth, and also produced identical pigmentation during growth on Pseudomonas isolation medium, thus eliminating the possibility of contamination. However, all attempts to isolate a single morphological type which subsequently fully expressed high activities during growth in continuous culture failed. The reason for this is unclear, but it is possible that the isolation of single colonies on solid medium and their subsequent growth in batch culture prior to continuous culture rapidly selects against the over-expressing strains.

The extent to which over-expression of glycerol uptake/ glycerol kinase and glycerol-3-phosphate dehydrogenase by culture $C$ was constitutive was examined by switching the culture to succinate limitation $\left(D, 0.05 \mathrm{~h}^{-1}\right)$ and measuring the activities and/or concentrations of these enzymes (Fig. 4). Within nine generations these had

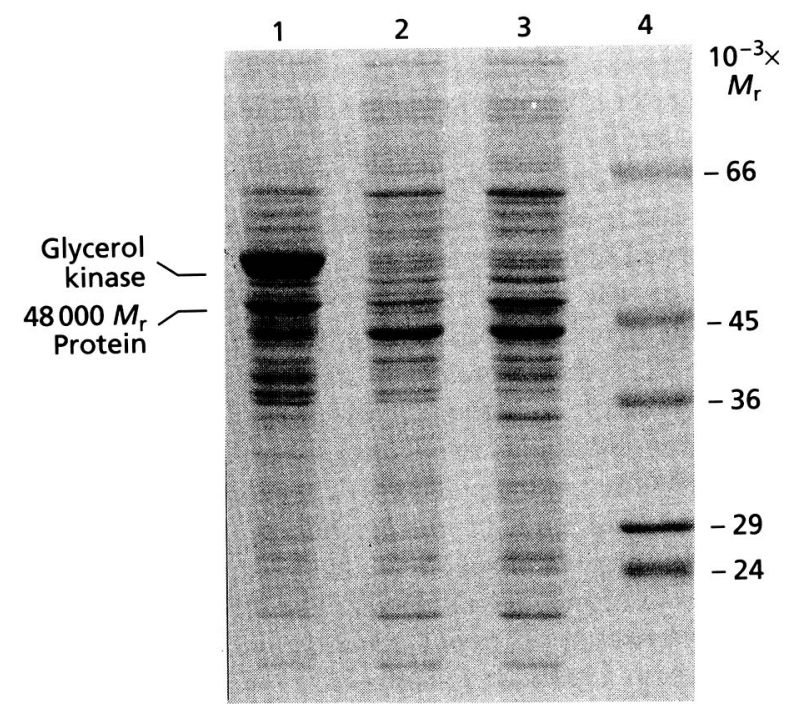

Fig. 4. Expression of glycerol kinase and the $48000 M_{\mathrm{r}}$ protein following the growth of $P$. aeruginosa culture $C$ in continuous culture under different carbon limitations. Washed cell samples were subjected to SDS-PAGE $(30 \mu \mathrm{g}$ protein per track) as described in Methods. Tracks: 1, glycerol limitation; 2, succinate limitation; 3, glucose limitation; $4, M_{r}$ standards.

declined by over $92 \%$, compared with a decrease of $77 \%$ for the $48000 M_{\mathrm{r}}$ protein and a threefold increase in the rate of $\left[{ }^{14} \mathrm{C}\right]$ succinate uptake, but were still significantly higher than those exhibited by the wild-type culture growing under the same conditions. Furthermore, when the culture was then switched to glucose limitation $(D$, $0.05 \mathrm{~h}^{-1}$ ) the activities and/or concentrations of these enzymes remained essentially unchanged (and hence significantly higher than those of the wild-type culture grown under the same conditions), whereas the concentration of the $48000 M_{\mathrm{r}}$ protein increased substantially. This differential expression of glycerol uptake/ glycerol kinase compared with the $48000 M_{\mathrm{r}}$ protein suggested that they are not regulated co-ordinately, and that the latter is produced either as a general response to carbon limitation or as a more specific response to glycerol and glucose limitation.

\section{Characterization of the $48000 M_{r}$ outer-membrane protein}

The $48000 M_{\mathrm{r}}$ protein was primarily associated with the outer membrane (Table 3) and displayed OmpA-like heat modifiability (Hancock et al., 1990) on SDS-PAGE, i.e. its apparent $M_{\mathrm{r}}$ decreased from 48000 to 36300 when solubilized in SDS sample buffer at $37^{\circ} \mathrm{C}$ instead of $100^{\circ} \mathrm{C}$. This type of behaviour is characteristic of some outer-membrane porins in bacteria, including that responsible for the transport of glucose (OprB or D1; 47500 to 35500 ) in P. aeruginosa (see Wylie et al., 1993). The protein was easily removed from the membrane with $0.2 \%(\mathrm{w} / \mathrm{v})$ SDS, indicating that it was not tightly bound to the peptidoglycan, but its readiness to aggregate under these conditions prevented determination of its native $M_{\mathrm{r}}$. 
In order to investigate whether the $48000 M_{\mathrm{r}}$ protein was over-expressed specifically in response to prolonged growth under glycerol limitation, the wild-type organism was also grown for a prolonged period in continuous culture under glucose limitation $\left(D, 0.05 \mathrm{~h}^{-1}\right)$. A significant increase in the rate of glucose uptake by washed cells was observed which was accompanied by a corresponding increase in the concentration of a $48000 M_{\mathrm{r}}$ outermembrane protein. Furthermore, the effect of heat on the apparent $M_{\mathrm{r}}$ of this protein was identical to that observed during glycerol limitation, suggesting that the same protein was over-expressed under both nutrient limitations. This was confirmed by showing that the $\mathrm{N}$-terminal amino acid sequence of the $48000 M_{\mathrm{r}}$ protein was the same following prolonged growth under glycerol or glucose limitation (AEAFSPN-). The latter was identical to the $\mathrm{N}$-terminal sequence recently determined for the glucose porin OprB of P. aeruginosa (Wylie et al., 1993), but exhibited no homology with those of other similarly sized, heat-modifiable Pseudomonas and E. coli porins (OprD, FadL, OprF, OprO and OprP). It was concluded that $\mathrm{OprB}$ acts as a porin for glycerol as well as glucose in $P$. aeruginosa, a role commensurate with its high expression following prolonged growth under glucose or glycerol limitation.

\section{DISCUSSION}

Previous investigations of glycerol uptake by $P$. aeruginosa have implicated a binding-protein-dependent active transport system (Tsay et al., 1971; Siegel \& Phibbs, 1979), and energy-dependent glycerol uptake has also been reported for Streptomyces clavuligerus (Miñambres et al., 1991). In contrast, all other species of bacteria so far investigated have been reported to take up glycerol passively by facilitated diffusion, e.g. E. coli (Lin, 1976), Bacillus subtilis (Beijer \& Rutberg, 1992) and Ent. faecalis (Romano et al., 1990). The results described in this paper indicate that this is also the case for $P$. aeruginosa NM48. Furthermore, the properties of the glycerol uptake system, glycerol kinase and glycerol-3-phosphate dehydrogenase (see also Weissenborn et al., 1992), including the propensity of the kinase to be associated with the inner membrane, are very similar to those reported for E. coli (Lin, 1976; Voegele et al., 1993).

Simple considerations of glycerol diffusion rates at low concentrations of glycerol highlight the requirement for bacteria to synthesize a glycerol transport system in spite of the high diffusion coefficient exhibited by this solute. During batch culture (i.e. at glycerol concentrations in the millimolar range) glycerol can undoubtedly enter the cell by simple diffusion at a rate sufficient to support the observed growth rate. In contrast, during growth in continuous culture under glycerol limitation (i.e. at glycerol concentrations in the low micromolar range) the rate of glycerol entry by simple diffusion $\left[0.63 \mathrm{nmol} \mathrm{min}^{-1}\right.$ (mg dry wt cells) ${ }^{-1}$ at $50 \mu \mathrm{M}$ : Voegele et al., 1993] would be only approximately one-fiftieth of the rate required to support the imposed growth rate $\left[q_{\text {glycerol }} 31 \mathrm{nmol} \mathrm{min}^{-1}\right.$ (mg dry wt cells) $)^{-1}$ at $\left.D=0.05 \mathrm{~h}^{-1}\right]$, thus confirming the necessary involvement of a transport system during growth under these conditions. Continued glycerol uptake under steady-state conditions is probably determined by the subsequent ability of the glycerol kinase to phosphorylate the transported solute and hence maintain a glycerol concentration gradient. Definitive confirmation of a glycerol permease in strain NM48 would require purification of the protein and its insertion into blacklipid bilayers with an appropriate increase in permeability at low concentrations of glycerol, the isolation of $g l p T$ deletion mutants and/or the identification of GlpT as a transmembrane protein by gene sequencing.

Prolonged growth of $P$. aeruginosa NM48 under glycerol limitation led to substantial over-production of the glycerol uptake system, glycerol kinase and glycerol-3phosphate dehydrogenase, together with a $48000 M_{r}$ outer-membrane protein. The latter, which was also overexpressed during prolonged growth under glucose limitation, was identified as the previously characterized glucose porin OprB. Given that over-expression of proteins under these conditions is always of physiological significance (Harder et al., 1977), it was concluded that OprB is an outer-membrane porin for both glucose and glycerol which is over-expressed during growth under either glucose or glycerol limitation in order to facilitate the passage of low concentrations of these substrates through the outer membrane. The maltoporin LamB, which facilitates the passage of glucose and glycerol through the outer membrane of $E$. coli, is derepressed under similar conditions to OprB and confers a selective advantage on LamB ${ }^{+}$cells during growth under either glucose or glycerol limitation (Death et al., 1993).

The growth of culture $\mathrm{C}$ under succinate-limited conditions showed that glycerol uptake, glycerol kinase and glycerol-3-phosphate dehydrogenase were more strongly repressed than the outer-membrane porin OprB, although all of these enzymes showed some degree of constitutivity compared with the wild-type culture, suggesting that their over-expression is more likely to be the result of a regulatory mutation rather than gene duplication. Furthermore, as $P$. aeruginosa utilizes organic acids in preference to glucose and other carbon sources, a phenomenon which is mediated by the product of the crc gene (MacGregor et al., 1991) it is likely that expression of the first three enzymes reflects the availability of a suitable inducer, whereas expression of $\mathrm{OprB}$ is controlled via catabolite repression (Hancock \& Carey, 1980).

\section{ACKNOWLEDGEMENTS}

This work was supported by the Wellcome Trust. The authors are indebted to Katherine Lilley and Elizabeth Cavanagh for carrying out the $\mathrm{N}$-terminal amino acid sequencing.

\section{REFERENCES}

Beijer, L. \& Rutberg, L. (1992). Utilisation of glycerol and glycerol 3 -phosphate is differently affected by the phosphotransferase system in Bacillus subtilis. FEMS Microbiol Lett 100, 217-220.

Cheng, K. J., Ingram, J. M. \& Costerton, J. W. (1970). Release of alkaline phosphatase from cells of Pseudomonas aeruginosa by manipulation of cation concentration and of $\mathrm{pH}$. J Bacteriol 104, 748-753. 
Cornish, A., Greenwood, J. A. \& Jones, C. W. (1988). Bindingprotein-dependent glucose transport by Agrobacterium radiobacter grown in glucose-limited continuous culture. J Gen Microbiol 134, 3099-3110.

Dawson, R. M. C., Elliott, D. C., Elliott, W. C. \& Jones, K. M. (1986). Data for Biochemical Research, 3rd edn, pp. 485-486. Oxford: Oxford University Press.

Death, A., Notley, L. \& Ferenci, T. (1993). Derepression of LamB protein facilitates outer membrane permeation of carbohydrates into Escherichia coli under conditions of nutrient stress. $J$ Bacteriol 175, 1475-1483.

Deretic, V. \& Konyecsni, W. M. (1989). Control of mucoidy in Pseudomonas aeruginosa: transcriptional regulation of $a \lg R$ and identification of the second regulatory gene, algQ.J Bacteriol 171, 3680-3688.

Deretic, V., Govan, J. R. W., Konyecsni, W. M. \& Martin, D. W. (1990). Mucoid Pseudomonas aeruginosa in cystic fibrosis: mutations in the muc loci affect transcription of the $\operatorname{alg} R$ and $\operatorname{alg} D$ genes in response to environmental stimuli. Mol Microbiol 4, 189-196.

DeVault, J. D., Kimbara, K. \& Chakrabarty, A. M. (1990). Pulmonary dehydration and infection in cystic fibrosis: evidence that ethanol activates alginate gene expression and induction of mucoidy in Pseudomonas aeruginosa. Mol Microbiol 4, 737-745.

Govan, J. R. W., Martin, D. W. \& Deretic, V. P. (1992). Mucoid Pseudomonas aeruginosa and cystic fibrosis: the role of mutations in muc loci. FEMS Microbiol Lett 100, 323-330.

Hancock, R. E. W. \& Carey, A. M. (1980). Protein D1 -- a glucoseinducible, pore-forming protein from the outer membrane of Pseudomonas aeruginosa. FEMS Microbiol Lett 8, 105-109.

Hancock, R. E. W. \& Nikaido, H. (1978). Outer membranes of Gram-negative bacteria XIX. Isolation from Pseudomonas aeruginosa $\mathrm{PAO} 1$ and use in reconstitution and definition of the permeability barrier. J Bacteriol 136, 381-390.

Hancock, R. E. W., Siehnel, R. H. \& Martin, N. (1990). Outer membrane proteins of Pseudomonas. Mol Microbiol 4, 1069-1075.

Harder, W., Kuenen, J. G. \& Matin, A. (1977). A review : microbial selection in continuous culture. $J$ Appl Bacteriol 43, 1-24.

Heller, K. B., Lin, E. C. C. \& Wilson, T. H. (1980). Substrate specificity and transport properties of the glycerol facilitator of Eschericbia coli. J Bacteriol 144, 274-278.

Kasahara, M. \& Anraku, Y. (1974). Succinate dehydrogenase of Escherichia coli membrane vesicles: activation and properties of the enzyme. $J$ Biochem 76, 959-966.

Lin, E. C. C. (1976). Glycerol dissimilation and its regulation in bacteria. Annu Rev Microbiol 30, 535-578.

MacGregor, C. H., Wolff, J. A., Arora, S. K. \& Phibbs, P. V. (1991). Cloning of a catabolite repression control ( $\mathrm{crc}$ ) gene from $P$ seudomonas aeruginosa, expression of the gene in Escherichia coli, and identification of the gene product in Pseudomonas aeruginosa. $J$ Bacteriol 173, 7204-7212.

Marty, N., Dournes, J., Chabanon, G. \& Montrozier, H. (1992). Influence of nutrient media on the chemical composition of the exopolysaccharide from mucoid and non-mucoid Pseudomonas aeruginosa. FEMS Microbiol Lett 98, 35-44.

May, T. B., Shinabarger, D., Maharaj, R., Kato, J., Chu, L., DeVault, J. D., Roychoudhury, S., Zielinski, N. A., Berry, A., Rothmel, R. K., Misra, T. K. \& Chakrabarty, A. M. (1991). Alginate synthesis by Pseudomonas aeruginosa: a key pathogenic factor in chronic pulmonary infections of cystic fibrosis patients. Clin Microbiol Rev 4, 191--206.
McCowen, S. A., Phibbs, P. V. \& Feary, T. W. (1981). Glycerol catabolism in wild-type and mutant strains of $P$ seudomonas aeruginosa. Curr Microbiol 5, 191-196.

McCowen, S. A., Sellers, J. R. \& Phibbs, P. V. (1987). Characterisation of fructose-1,6-diphosphate-insensitive catabolite glycerol kinase of Pseudomonas aeruginosa. Curr Microbiol 14, 323-327.

Mian, F. A., Jarman, T. R. \& Righelato, R. C. (1978). Biosynthesis of exopolysaccharide by Pseudomonas aeruginosa. J Bacteriol 134, 418422.

Miñambres, B., Reglero, A. \& Luengo, J. M. (1991). Characterisation of an inducible transport system for glycerol in Streptomyces clavuligerus: repression by L-serine. I Antibiot 45, 269-277.

Osborn, M. J. (1963). Studies on the Gram-negative cell wall, I. Evidence for the role of 2-keto-3-deoxyoctonate in the lipolysaccharide of Salmonella typhimurium. Biochemistry 50, 499-506.

Romano, A. H., Saier, M. H., Harriott, O. T. \& Reizer, J. (1990). Physiological studies on regulation of glycerol utilization by the phosphenolpyruvate:sugar phosphotransferase system in Enterococcus faecalis. J Bacteriol 172, 6741-6748.

Schweizer, H.P. (1991). The agm R gene, an environmentallyresponsive gene, complements defective $g l p R$, which encodes the putative activator for glycerol metabolism in Pseudomonas aeruginosa. J Bacteriol 173, 6798-6806.

Siegel, L. S. \& Phibbs, P. V. (1979). Glycerol and L- $\alpha$-glycerol-3phosphate uptake by Pseudomonas aeruginosa. Curr Microbiol 2, 251-256.

Stinson, M. W., Cohen, M. A. \& Merrick, J. M. (1976). Isolation of dicarboxylic acid- and glucose-binding proteins from Pseudomonas aeruginosa. J Bacteriol 128, 573-579.

Terry, J. M., Pina, S. E. \& Mattingly, S. J. (1991). Environmental conditions which influence mucoid conversion in Pseudomonas aeruginosa PAO1. Infect Immun 59, 471-477.

Terry, J. M., Pina, S. E. \& Mattingly, S. J. (1992). Role of energy metabolism in conversion of nonmucoid Pseudomonas aeruginosa to the mucoid phenotype. Infect Immun 60, 1329-1335.

Tsay, S. S., Brown, K. K. \& Gaudy, E. T. (1971). Transport of glycerol by Pseudomonas aeruginosa. J Bacteriol 108, 82-88.

Voegele, R. T., Sweet, G. D. \& Boos, W. (1993). Glycerol kinase of Eschericbia coli is activated by interaction with the glycerol facilitator. J Bacteriol 175, 1087-1094.

Weissenborn, D. L., Wittekindt, N. \& Larson, T. J. (1992). Structure and regulation of the $g l p F K$ operon encoding glycerol diffusion facilitator and glycerol kinase of Escherichia coli K-12. J Biol Chem 267, 6122-6131.

Williams, S. G., Greenwood, J. A. \& Jones, C. W. (1990). Isolation of novel strains of Agrobacterium radiobacter with altered capacities for lactose metabolism and succinoglucan production. $J \mathrm{Gen}$ Microbiol 136, 2179-2188.

Wylie, J. L., Bernegger-Egli, C., O’Neil, J. D. J. \& Worobec, E. A. (1993). Biophysical characterization of $\mathrm{OprB}$, a glucose-inducible protein of Pseudomonas aeruginosa. J Bioenerg Biomembr 25, 547-556.

Zielinski, N. A., Maharaj, R., Roychoudhury, S., Danaganan, C. E., Hendrickson, W. \& Chakrabarty, A. M. (1992). Alginate synthesis in Pseudomonas aeruginosa: environmental regulation of the $\operatorname{alg} C$ promoter. J Bacteriol 174, 7680-7688.

Received 7 March 1994; revised 14 June 1994; accepted 5 August 1994. 